\title{
In Vitro Bacteriostatic and Bactericidal Activities of Senna Alata, Ricinus Communis and Lanneabarteri Extracts Against Wound and Skin Disease Causing Bacteria
}

\begin{abstract}
Antibacterial activities of the extracts of three medicinal plants, Senna alata, Ricinus communis and Lannea barteri from two different extractants were studied. Bacteria strains such as Staphylococcus aureus, Pseudomonas aeruginosa, Klebsiella pneumoniae and Escherichia coli are known wound and skin disease causing bacteria. For $100 \mathrm{~g}$ of each plant material, the percentage yields of the extracts were determined and ranged between $5.20 \%$ and $12.40 \%$. Phytochemical screening of the crude extracts of Senna alata, Ricinus communis and Lannea barteri revealed the presence of some bioactive components, including tannins, anthraquinones, saponins, flavonoids and alkaloids. All plant extracts showed inhibition on test organisms and were in the range of $12.0 \pm 2.83 \mathrm{~mm}$ to $36.0 \pm$ $2.12 \mathrm{~mm}$ for all the extracts. The MIC values obtained for the entire test ranged from $3.13 \mathrm{mg} /$ $\mathrm{ml}$ to $12.50 \mathrm{mg} / \mathrm{ml}$ and $\mathrm{MBC}$ values were found to be $200 \mathrm{mg} / \mathrm{ml} \mathrm{minimum}$ and $400 \mathrm{mg}$ / $\mathrm{ml}$ maximum. Findings support the traditional use of Senna alata, Ricinus communis and Lannea barteri for the treatment of skin and wound infections and form a strong basis for further exploration of these plants.
\end{abstract}

Keywords: Bacteriostatic; Bactericidal; Senna alata, Ricinus communis; Lannea barteri; Staphylococcus aureus; Pseudomonas aeruginosa; In vitro
Volume 3 Issue I - 2016

\author{
Addai Mensah Donkor, Richard Mosobil, \\ Jennifer Suurbaar \\ Department of Chemistry and Biochemistry, University for \\ Development Studies, Ghana
}

\begin{abstract}
Correspondence: Suurbaar Jennfer, Department of Chemistry and Biochemistry, University for development studies, Ghana, Tel $+233506362322$
\end{abstract}

Email jenniferexpress@yahoo.com, suurbaar@gmail.com

Received: July 22, 2016 | Published: September 02, 2016
Abbreviations: S. Alata, Senna Alata; R. Communis, Ricins Communis; L. Bartari, Lannea Barteri; K. Pneumoniae, Klebsiella Pneumoniae; E. Coli, Escherichia Coli; P. Aeruginosa, Psedomonas Aeruginosa; S. Aureus, Staphylococcus Aureus; MIC, minimum inhibitory contration; $\mathrm{MBC}$, minimum bactericidal concentration; STD, standard deviation

\section{Introduction}

Plants in several families of the plant kingdom have been used for centuries in medicine. These plants are found worldwide but they are most abundant in tropical countries. ${ }^{1}$ These plants are sources of many chemical compounds, the most important of which are alkaloids, terpenoids, steroids phenols, glycosides and tannins. A number of modern drugs have been isolated from plants and the screening of plant extracts for antimicrobial activity has shown that higher plants represent a potential source of novel antibiotics. ${ }^{2}$

Due to some antibacterial ineffectiveness, there is an increase in the population of patients that visit medical centers in developing countries. The problem of antibiotic resistance has led to the revival of interest in herbal products as sources of novel compounds to suppress the ever increasing problems of re-emergence of diseases. A large group of microbial pathogens are associated with various skin infections. The streptococci and staphylococci cause wound infections. These microbes cause opportunistic skin infections in immunosuppressed patients.

The E. coli are part of physiological intestinal flora, however outside the intestine they may cause wound infection and sepsis. ${ }^{3}$ Pseudomonas aeruginosa is a prevalent burn patient pathogen; this microbe is able to infect different parts of human body. ${ }^{4}$
Senna alata belongs to the family Caesalpinaceae. The shrub stand 3-4 meter tall with leaves up to $50-80 \mathrm{~cm}$ long; the inflorescence looks like a yellow candle. The plant has fungicidal properties for treating ringworm and other infections of the skin. ${ }^{5}$ Abatan, ${ }^{6}$ reported that leaf juice and decoction of senna alata are used in the treatment of ringworm and other skin diseases. ${ }^{6}$ Ricinus communis is from the Family Euphorbiaceae, popularly known as castor plant. The plant is wide spread throughout tropical regions as ornamental plant. The antimicrobial activities of Ricinus communis were good against dermatophytic and pathogenic bacterial strains Staphylococcus aureus, Pseudomonas aeruginosa as well as Klebsiella pneumoniae, Escherichia coli. ${ }^{7}$ The Ricinus communis possess wound healing activity due to the active constituent of castor oil which produces antioxidant activity and inhibits lipid peroxidation. A study conducted by Prasad et al. ${ }^{8}$ reported the potential of Castor oil in wound healing activity by reducing the scar area and also the epithelization time in excision wound model. ${ }^{8}$ Lannea barteri belongs to the family Anacardiaceae and they are used as medicinal plants in most African countries for curing some infectious diseases. ${ }^{9}$ In this study, we validated the antibacterial activity of the extracts of Senna alata, Ricinus communis and Lannea barteri from aqueous and ethanolic solvent

\section{Materials and methods}

\section{Plant material}

Plant materials of Senna alata (leaves), Ricinus commmunis (leaves) and Lannea barteri (bark) were collected from different areas in Navrongo, Upper East Region, Ghana. The plants were authenticated by Dr. Isaac Sackey in the Department of Applied Biology, University for Development Studies, Ghana. 
Table I Phytochemical profile of plant extract

\begin{tabular}{|c|c|c|c|c|c|c|c|c|}
\hline \multicolumn{9}{|l|}{ Pyhtochemicals } \\
\hline Plants/ Solvents & Tannins & Saponins & Poluronoids & Reducing & Sugars & Terpenoids & Flavonoids & Alkaloids \\
\hline \multicolumn{9}{|l|}{ Senna alata } \\
\hline Aqueous & + & + & + & + & + & + & + & + \\
\hline Ethanolic & + & + & - & + & + & + & + & + \\
\hline \multicolumn{9}{|l|}{ Lannea barteri } \\
\hline Aqueous & + & + & + & + & + & + & + & + \\
\hline Ethanolic & + & + & + & + & + & + & + & + \\
\hline \multicolumn{9}{|l|}{ Recinis communis } \\
\hline Aqueous & + & + & + & + & + & + & + & - \\
\hline Ethanolic & + & + & + & - & - & + & + & - \\
\hline
\end{tabular}

+: Presence; -: not Detected

Table 2 MIC and MBC of the plant extract Senna alata on the bacterial strains

\begin{tabular}{|c|c|c|c|c|}
\hline \multicolumn{5}{|l|}{ Senna Alata } \\
\hline \multirow{2}{*}{ Test organisms } & \multicolumn{2}{|c|}{ Aqueous extract (mg/ml) } & \multicolumn{2}{|c|}{ Ethanolic extract $(\mathrm{mg} / \mathrm{ml})$} \\
\hline & MIC & MBC & MIC & MBC \\
\hline E. coli & 3.13 & 200 & 6.25 & 200 \\
\hline S. aureus & 12.5 & 300 & 12.5 & 300 \\
\hline P. aeruginosa & 6.25 & 200 & 6.25 & 200 \\
\hline K. pneumoniae & 6.25 & 200 & 12.5 & 300 \\
\hline
\end{tabular}

Table 3 MIC and MBC of the plant extract, Lannea barteri, on the bacterial strains

\begin{tabular}{lllll}
\hline Lannea Barteri & \multicolumn{5}{l}{} \\
\hline \multirow{2}{*}{ Test organisms } & \multicolumn{2}{l}{ Aqueous extract $(\mathbf{m g} / \mathbf{m l})$} & \multicolumn{2}{l}{ Ethanolic extract $\mathbf{~ m g} / \mathbf{m l})$} \\
\cline { 2 - 5 } & MIC & MBC & MIC & MBC \\
\hline E. coli & 6.25 & 300 & 6.25 & UD \\
S. aureus & 12.5 & 200 & 25 & 400 \\
P. aeruginosa & 6.25 & 200 & 6.25 & 200 \\
K. pneumoniae & 12.5 & 200 & 6.25 & 200 \\
\hline
\end{tabular}

*UD - undetected

Table 4 MIC and MBC of the plant extract Ricinis communis on the bacterial strains

\begin{tabular}{|c|c|c|c|c|}
\hline \multicolumn{5}{|c|}{ Ricinis communis } \\
\hline \multirow{2}{*}{ Test organisms } & \multicolumn{2}{|c|}{ Aqueous extract (mg/ml) } & \multicolumn{2}{|c|}{ Ethanolic extract $(\mathrm{mg} / \mathrm{ml})$} \\
\hline & MIC & MBC & MIC & MBC \\
\hline E. coli & 6.25 & UD & 6.25 & UD \\
\hline S. aureus & 3.13 & 300 & 25 & 400 \\
\hline$P$. aeruginosa & 3.13 & 200 & 6.25 & 200 \\
\hline K. pneumoniae & 12.5 & 400 & 6.25 & 200 \\
\hline
\end{tabular}

8UD - Undetected

\section{Preparation of plant crude extracts}

Plants materials from Senna alata (leaves), Ricinus commmunis (leaves) and Lannea barteri (bark) were air dried at room temperature for 2 weeks. The respective leaves were ground into uniform powdered using a blender and the back was powdered using pestle and mortar.

The ethanol and water extracts were prepared by socking $100 \mathrm{~g}$ each of the powdered plant materials in $1 \mathrm{~L}$ of solvent at room temperature for $48 \mathrm{~h}$. The extracts were filtered separately through Whatman filter paper No 42. The extracts were concentrated using a rotary evaporator and further warmed in a water bath to obtain semi-solid and solid products.

\section{Phytochemical screening}

Phytochemical screening for all plant extracts was done for the presence of tannins, saponins, terpenoids, puloronoids, reducing sugars, flavanoids, alkaloids and anthraquinones. The presence of alkaloids was detected by following a method described by Fernand et al. ${ }^{10}$ The sample was basified with ammonium hydroxide, extracted with chloroform and subsequently warmed in a water bath to remove traces of chloroform. The residue was dispersed in $2 \mathrm{~N} \mathrm{HCl}$ and a few drops of Mayer's reagent were added. Presence of yellowish cloudy precipitate indicated a positive test for alkaloids. Saponins were tested by adding $4 \mathrm{ml}$ of water to the sample and shaking vigorously for 10 15 mins. Persistence of foamy layer indicated saponins were present. ${ }^{10}$ Tannins were also detected by adding $4.0 \mathrm{ml}$ of distilled water to $2.0 \mathrm{ml}$ of sample. A few drops of $10 \%$ ferric chloride solution were then added and a blue-black color was observed indicating the presence of tannins. ${ }^{11}$ A few drops of acetone were added to a portion of the sample resulting in a precipitate sticking along the walls of the test tube reminiscent of the presence of polyuronoids. ${ }^{10}$ The presence of reducing sugars was verified by adding equal volumes of Fehling's 
solution A and B to the sample and heating in a water bath for $15 \mathrm{mins}$. Brick-red precipitate indicated the presence of reducing sugars. ${ }^{10}$ Flavonoids were detected using Shibata's reaction test as the extracts were evaporated to dryness and the residue was dissolved using $50 \%$ methanol in a test tube. A piece of magnesium was dropped into the mixture, followed by 3 drops of concentrated $\mathrm{HCl}$ with subsequent appearance of orange color indicative of the presence of flavonoids. ${ }^{10}$

\section{Antibacterial activity of the plant extracts}

Preparation of plant extracts concentrations: The crude extracts obtained from the respective solvents were prepared using dimethylsulfuroxide (DMSO). Stock solutions, $400 \mathrm{mg} / \mathrm{ml}$ concentration was prepared by adding $0.4 \mathrm{~g}$ of each extract in $1 \mathrm{ml}$ of DMSO in sterile containers. Serial dilutions were carried out to obtain concentrations of $200 \mathrm{mg} / \mathrm{ml}, 100 \mathrm{mg} / \mathrm{ml}, 50 \mathrm{mg} / \mathrm{ml}, 25 \mathrm{mg} / \mathrm{ml}$, $12.5 \mathrm{mg} / \mathrm{ml}, 6.25 \mathrm{mg} / \mathrm{ml}, 3.125 \mathrm{mg} / \mathrm{ml}$ and $1.5625 \mathrm{mg} / \mathrm{ml}$ of extracts concentration.

Test organism: Wound and skin disease causing bacteria were taking into consideration and four of these bacterial were considered. Selected bacterial were Escherichia coli, Staphylococcus aureus, Pseudomonas aeruginosa and Klebsiella pneumoniae. Clinical isolates of the bacterial were obtained from the Microbiology Department of the Tamale Teaching Hospital in the Northern Region of Ghana, in March 2016. Bacterial isolates were stored at temperatures between $2^{\circ} \mathrm{C}$ and $8^{\circ} \mathrm{C}$ in nutrient broth until further analysis.

Agar well diffusion assay: The agar well diffusion method was employed, where Molten Mueller Hinton agar (OXOID, Basingstoke, Hampshire, England) at $40^{\circ} \mathrm{C}$ was poured aseptically into sterile petri dishes (about $6 \mathrm{~mm}$ thick) and allowed to solidify. Test organisms in normal saline were spread on the solidified agar. Wells, $6 \mathrm{~mm}$, were created and filled with $1.0 \mathrm{ml}$ of the various concentrations of the plant extracts. DMSO was used as negative control while Amoxicillin $250 \mathrm{mg} / \mathrm{ml}$ was used as a positive control. Test were carried out in duplicates and plates were allowed to stand for $30 \mathrm{mins}$ at room temperature and finally incubated at $37^{\circ} \mathrm{C}$ for $24 \mathrm{~h}$. The antibacterial activity was evaluated by measuring the diameter of zones of inhibition in milimeters ( $\mathrm{mm}$ ).

Inoculum preparation for minimum inhibitory concentration (MIC) and minimum bactericidal concentrations (MBC): Inocula were obtained from an overnightagar culture of the test organism. Inoculum for the MIC and MBC test was prepared by taking at least three to five well isolated colonies of the same morphology from agar plate culture. The top of each colony was touched with a sterile loop and the group was transferred into a tube containing $5 \mathrm{ml}$ of normal saline and then vortexed. The broth culture was incubated at $37^{\circ} \mathrm{C}$ unti lit achieved the turbidity of $0.5 \mathrm{McF}$ arland standard $(1.0 \times 106$ cfu) for 6 hours.

Preparation of McFarland standard (Turbidity standard MIC and MBC for inoculum): Barium sulphate turbidity standard equivalent to a $0.5 \mathrm{McF}$ arland was used to standardize the inoculum density for susceptibility test. ${ }^{12}$ To make the turbidity standard 0.5 McFarland, Barium chloride solution, $200 \mathrm{ml}, 175 \% \mathrm{w} / \mathrm{v}$, was added to $99.5 \mathrm{ml} 1 \%$ sulphuric acid solution, mixed well and stored in the dark at room temperature.

Determination of minimum bacteriocidal concentration (MBC): The tube diffusion method was employed for the determination of MBCs. ${ }^{13}$ Minimum bactericidal concentrations of the extract was prepared by using sterilized transparent bottles for the different organisms cultured. Normal saline solution, $2 \mathrm{ml}$, containing the test organisms was each dispensed into the sterilized transparent bottles. A $1 \mathrm{ml}$ extract of different concentrations was dropped into sterile transparent bottles containing the test organisms.The bottles were corked and incubated aerobically at $37^{\circ} \mathrm{C}$ for $24 \mathrm{~h}$. Sterile nutrient agar plates were inoculated with sample from each of the transparent bottles . The plates were further incubated for $24 \mathrm{~h}$ at $37^{\circ} \mathrm{C}$ and subsequently observed for bacterial growth. The lowest concentration that killed $100 \%$ of the inoculum bacteria, thus, no growth on plate was recorded as the MBC.

Determination of minimum inhibitory concentration (MIC): Minimum inhibitory concentration (MIC) of the extracts was carried out using the agar well diffusion method. Variable concentrations of the extract were prepared by serial dilution to obtain concentrations of $400 \mathrm{mg} / \mathrm{ml}, 200 \mathrm{mg} / \mathrm{ml}, 100 \mathrm{mg} / \mathrm{ml}, 50 \mathrm{mg} / \mathrm{ml}, 25 \mathrm{mg} / \mathrm{ml}, 12.5 \mathrm{mg} /$ $\mathrm{ml}, 6.25 \mathrm{mg} / \mathrm{ml}, 3.125 \mathrm{mg} / \mathrm{ml} 1.5625 \mathrm{mg} / \mathrm{ml}$. Nutrient broth, $2 \mathrm{ml}$, containing the test organisms was each dispensed into sterilized test tubes. A $1 \mathrm{ml}$ extract at varying concentrations was added to the test tubes containing the test organisms. The tubes were corked and incubated aerobically at $37^{\circ} \mathrm{C}$ for 24 hours. The tubes were observed after incubation to determine the MIC.

Statistical Analysis: Means and standard error of the mean were calculated for the zones of inhibition measured for the two sets of experiments in each case. These means were statistically compared using the one-way ANOVA to determine if they were significantly different at $\mathrm{P}<0.05$.

\section{Results and discussion}

The increasing use of medicinal plants by a sizable proportion of people in the industrial world has been traced to the extraction and development of several drugs from these plants as well as from traditionally used herbal remedies. Three medicinal plants were used in this study and their antibacterial activities were evaluated. The percentage yields were determined from $100 \mathrm{~g}$ of each plant material and were found to be between 5.20 and $12.40 \%$. Lannea barteri gave the highest yield; both aqueous and ethanolic extracts gave 12.40 and $12.10 \%$ respectively. Senna alata gave the second highest yield of 7.40 and $7.20 \%$ in aqueous and ethanolic respectively. The yields for aqueous and ethanolic extracts for Recinnus cominus were 6 and $5.20 \%$ respectively.

Phytochemical screening on Senna alata, Ricinus communis leaves extracts and Lannea barteri bark extract of the three extractants are indicated in Table 1. Tannins, saponins and alkaloids were present in all the plant extracts of their respective extractants. Polyrunoids, reducing sugars, terpenoids and flavonoids were found in all the plant extracts except Recinis communis which indicated absence of anthroquinones. These bioactive compounds have potentially significant application against bacteria, including those that cause wounds and skin diseases. ${ }^{14}$ Tannins are widely used in traditional medicine in treating wounds and to arrest bleeding. ${ }^{15}$ Some of these bioactive compounds which are synthesized as secondary metabolites as the plant grows, also serve to protect the plant against microbial attacks and predation by animals. ${ }^{16}$

Antibacterial activities of crude extracts of Senna alata, Recinnus communis and Lannea bartari were evaluated by measuring the diameters of zones of growth inhibition on bacteria. All test organisms used in this current research were susceptible to all the extracts though to varying degrees. The susceptibility of bacteria to plant extracts, on the basis of inhibition zone diameters varied according to strains and species as well as the extractants. All the plant extracts of both solvents 
gave inhibitory zones between $17.5 \pm 0.71 \mathrm{~mm}$ and $36.0 \pm 2.12 \mathrm{~mm}$ against $P$. aeruginosa. Both the ethanolic and aqueous extracts of Senna alata exhibited similar potency against the test organisms (Figure 1). The degree of inhibition of the different concentrations of the extracts on $P$. aeruginosa were higher than that of Amoxicillin, the positive control which gave between $15.0 \pm 0.71 \mathrm{~mm}$ and $16.5 \pm 2.12$ $\mathrm{mm}$ zones of inhibition on the test organism. Regarding L. barteri, the aqueous extract gave higher zones and hence higher potency than the ethanolic extracts at all concentrations used (Figure 2). Similar trends were also exhibited by the plant R. cummunis, in which aqueous extracts showed higher potency with higher zones of inhibition than the ethanolic extracts (Figure 3). All the bacteria used in this study were gram-negative bacteria except $S$. aureus which was gram positive. Gram negative bacteria are known to be resistant to the action of most antimicrobial agents including plant-based extracts. ${ }^{17}$ Nikaido et al. ${ }^{18}$ reported that gram-negative bacteria have an outer phospholipid membrane with the structural lipopolysaccharide components, which makes their cell wall impermeable to antimicrobial agents. ${ }^{18}$ Although $P$. aeruginosa is a gram negative bacterium, it was susceptible to the plant extracts in spite of permeability difference. Hence all the plant extracts used in this work would be considered as having broad spectrum inhibitory activity.

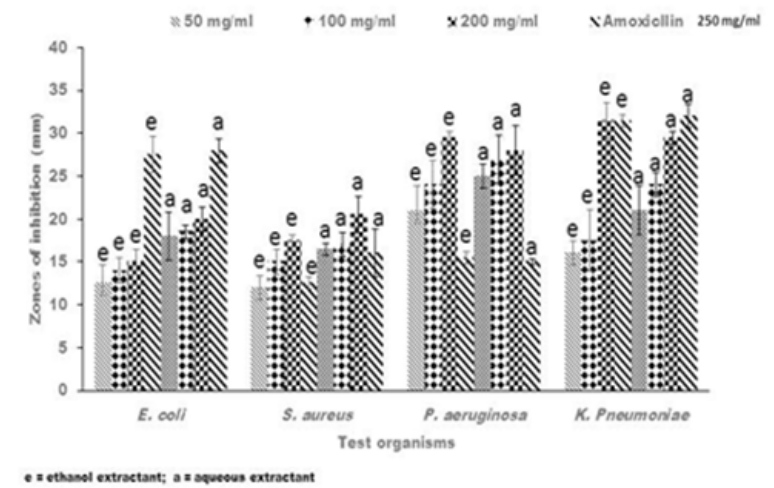

Figure I Representative antibacterial activity of ethanolic (e) and aqueous (a) crude extracts of Senna alata against E. coli, S. aureus, P. aeruginosa and $K$ pneumoniae. The data shown represent the average of three wells treated on the same day. The experiment was repeated 2 times and day-to-day variation was found to be within one fold of the presented data.

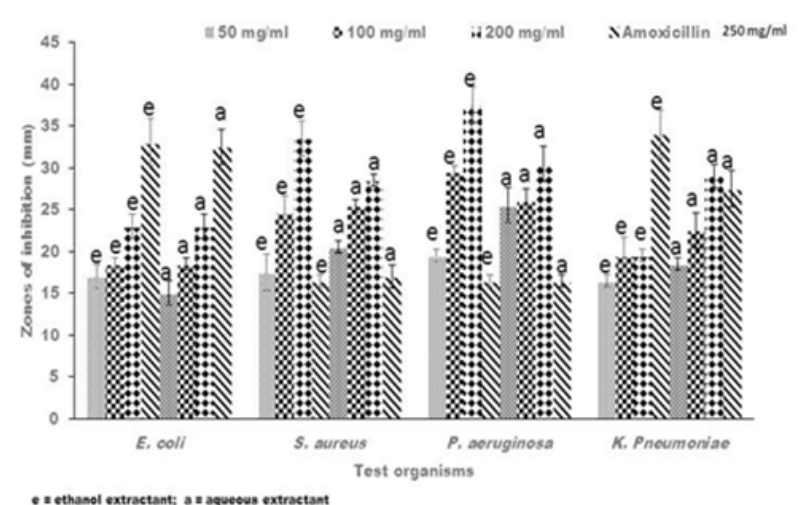

Figure 2 Representative antibacterial activity of ethanolic (e)) and aqueous (a) crude extracts of Lannea barteri against $E$. coli, S. aureus, P. aeruginosa and $K$. pneumoniae. The data shown represent the average of three wells treated on the same day. The experiment was repeated 2 times and day-to-day variation was found to be within one fold of the presented data.

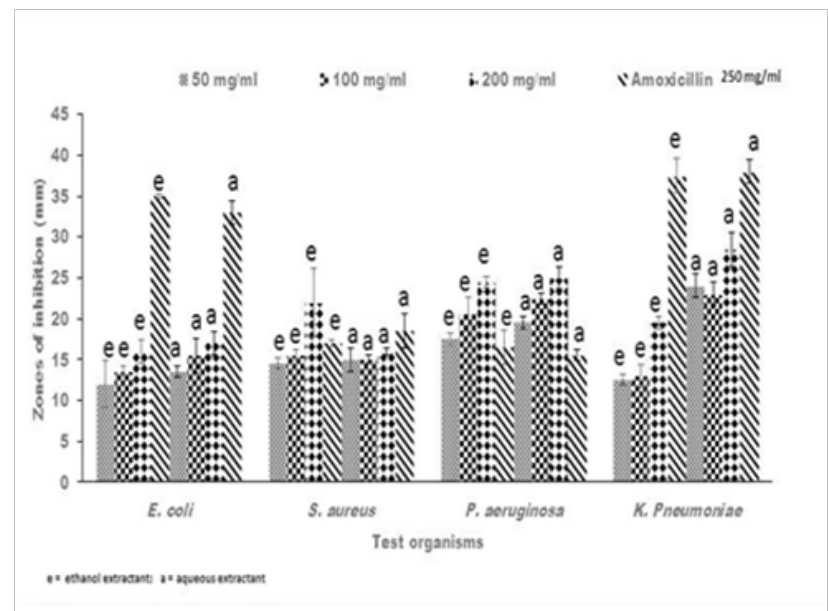

Figure 3 Representative antibacterial activity of ethanolic (e) and aqueous (a) crude extracts of Ricinus communis against $E$. coli, $S$. aureus, $P$. aeruginosa and $K$ pneumoniae. The data shown represent the average of three wells treated on the same day. The experiment was repeated 2 times and day-to-day variation was found to be within one fold of the presented data.

Antibacterial activities of $R$. communis and $S$. alata extracts against $P$. aeruginosa have been reported. ${ }^{19}$ The degree of inhibition of most of the concentrations of the extracts against $S$. aureus was also higher than the inhibition of Amoxicillin against S. aureus. This was consistent with other studies, ${ }^{5,19,20}$ which indicated that the bacterium was highly susceptible to the plant extracts. For the other test organisms, although there was inhibition, the amoxicillin exhibited higher activity than both aqueous and ethanolic extracts from all plant extracts applied in the current research. This could be attributed to the fact that unlike conventional antibiotics and other pharmaceutical products which are usually prepared from synthetic materials by means of reproducible manufacturing techniques and procedures, herbal medicinal products are prepared from materials of plant origin, which may be subjected to contamination, degradation or deterioration. The storage of extracts may require special condition of humidity, temperature and/or protection from light. Moreover, the plant extracts might contain little of the active ingredients.

Extracts with low activity against the organisms gave high MIC and $\mathrm{MBC}$ values, while the highly active ones gave low MIC and MBC values. The MIC and MBC techniques were used to evaluate the efficacies of antimicrobial agents and in this study, the MIC and $\mathrm{MBC}$ values tend to support the results obtained in the antibacterial screening (Tables 2-4). The MIC values obtained for the entire test ranged from $3.13 \mathrm{mg} / \mathrm{ml}$ to $12.50 \mathrm{mg} / \mathrm{ml}$ and $\mathrm{MBC}$ values from $200 \mathrm{mg} /$ $\mathrm{ml}$ as lowest and $400 \mathrm{mg} / \mathrm{ml}$ being highest. MBC was undetected for E. coli with Recinnus communis extracts; P. aeruginosa however indicated low MIC and MBC (Table 3) (Table 4). All the extracts showed inhibitory activities against skin and wound disease-causing pathogens used as demonstrated by similar works..$^{5,14,19-23}$ The efficacy of the plant extracts provide a scientific basis and thus validates their traditional use in the treatment of skin and wound diseases associated with these bacteria.

\section{Conclusion}

The antimicrobial results showed that the plants used in this study are highly bactericidal for broad spectrum activities. It also suggested that the plant extracts could be a potent raw material for pharmaceutical applications. 


\section{Acknowledgments}

We recognize the support by the research team of the Microbiology and Immunology Department, Navrongo Health Research Centre, Navrongo, UER, Ghana.

We also recognize the support Staff of the Faculty of Applied Sciences, University for Development Studies. Navrongo Campus, UER, Ghana.

\section{Conflicts of interest}

The authors declare there is no conflict of interests.

\section{Funding}

None.

\section{References}

1. Calixto JB. Twenty-five years of research on medicinal plants in Latin America:A personal view. J Ethnopharmacol. 2005;100(1-2):131-134.

2. Cowan MM. Plant products as antimicrobial agents. Clin Microbiol Rev. 1999;12(4):564-582.

3. Madigan MT, Martinko JM, Dunlap PV, et al. Brock Biology of microorganisms. 12th edn. International Microbiology. 2008;11:65-73.

4. Chanda S, Baravalia Y. Novel leads from herbal drugs for infectious skin diseases. Current Research, Technology and Education Topics in Applied Microbiology and Microbial Biotechnology. 2010;1:451-456.

5. Owoyale JA, Olatunji GA, Oguntoye S. Antifungal and antibacterial activities of an alcoholic extract of Senna alata leaves. Journal of Applied Sciences and Environmental Management. 2006;9(3):105-107.

6. Abatan M. A note on the anti-inflammatory action of plants of some Cassia species. Fitoterapia. 1990;61(4):336-338.

7. Jena J, Gupta AK. Ricinus communis Linn:a phytopharmacological review. International Journal of Pharmacy and Pharmaceutical Sciences. 2012;4(4):25-29.

8. Prasad MR, Shete R. Pharmacological investigation on the wound healing effects of castor oil in rats. International Journal of Universal Pharmacy and Life sciences. 2011;1(1):21-28.

9. Mahesh B, Satish S. Antimicrobial activity of some important medicinal plant against plant and human pathogens. World journal of agricultural sciences. 2008;4(5):839-843.

10. Fernand WN, Adama H, Jeanne FM, et al. Phytochemical composition, antioxidant and xanthine oxidase inhibitory activities of Amaranthus cruentus L. and Amaranthus hybridus L. Extracts. OALIB Journal. 1982. $67 \mathrm{p}$.
11. Sofowora E. Medicinal plants and Medicine in Africa. 2nd edn. USA: John Wiley and Sons; 1993.

12. Jean BP, Franklin RC, Patricia AB, et al. Performance standards for antimicrobial disk susceptibility tests: approved standard M2-A7. National Committee for Clinical Laboratory Standards. NCCLS 1997;35(1):1-15.

13. Lin J, Opoku AR, Geheeb KM, et al. Preliminary screening of some traditional Zulu medicinal plants for anti-inflammatory and antimicrobial activities. J Ethnopharmacol. 1999;68(1):267-274.

14. El-Mahmood A, Doughari J. Phytochemical screening and antibacterial evaluation of the leaf and root extracts of Cassia alata Linn. Afr J Pharm Pharmacol. 2008;2(7):124-129.

15. Begum D, Nath SC. Ethnobotanical review of medicinal plants used for skin diseases and related problems in Northeastern India. Journal of herbs, spices \& medicinal plants. 2000;7(3):55-93.

16. El-Mahmood AM, Doughari JH, Chanji F. In vitro antibacterial activities of crude extracts of Nauclea latifolia and Daniella oliveri. Scientific Research and Essay. 2008;3(3):102-105.

17. Ncube NS, Afolayan AJ, Okoh AI. Assessment techniques of antimicrobial properties of natural compounds of plant origin:current methods and future trends. African journal of biotechnology. 2008;7(12):1797-1806.

18. Nikaido H, Vaara M. Molecular basis of bacterial outer membrane permeability. Microbiol Mol Biol Rev. 1985;67(4):593-656.

19. Obumselu FO, Onwukeme VO, Eze R. Phytochemical and antibacterial analysis of the leaf extracts of Ricinus communis. Journal of Basic Physical Research. 2011;2(2).

20. Adegoke Sa, Agada fd, Ogundipe lo. Antibacterial activity of methanol and ethanol leaf extracts of Antidesma venosum and Lannea barteri. African Journal of Microbiology Research. 2013;7(27):3442-3447.

21. Benjamin T, Lamikanra A. Investigation of Cassia alata, a plant used in Nigeria in the treatment of skin diseases. Quarterly Journal of Crude Drug Research. 1981;19(2-3):93-96.

22. Parekh J, Jadeja D, Chanda S. Efficacy of aqueous and methanol extracts of some medicinal plants for potential antibacterial activity. Turk J Biol. 2006;29(4):203-210.

23. Dave H, Ledwani L. A review on anthraquinones isolated from Cassia species and their applications. Indian Journal of Natural Products and Resources. 2012;3(3):291-319. 